\title{
Topochemical investigations of cell walls in developing xylem of beech (Fagus sylvatica L.)*
}

\author{
Peter Prislan', Gerald Koch², Katarina Čufar ${ }^{1, \star \star}$, \\ Jožica Gričar $^{3}$ and Uwe Schmitt ${ }^{2}$ \\ 1 Department of Wood Science and Technology, \\ Biotechnical Faculty, University of Ljubljana, Ljubljana, \\ Slovenia \\ ${ }^{2}$ Institute for Wood Technology and Wood Biology, \\ Johann Heinrich von Thünen- Institute (vTI), Hamburg, \\ Germany \\ ${ }^{3}$ Department of Yield and Silviculture, Slovenian \\ Forestry Institute, Ljubljana, Slovenia \\ ${ }^{\star *}$ Corresponding author. \\ Department of Wood Science and Technology, Biotechnical \\ Faculty, University of Ljubljana, Rožna dolina, Cesta VIII/34, \\ SI-1000 Ljubljana, Slovenia \\ Phone: + 386-1-423-1161 \\ Fax: +386-1-423-5035 \\ E-mail: katarina.cufar@bf.uni-lj.si
}

\begin{abstract}
Formation and lignification of xylem cells in mature beech (Fagus sylvatica L.) trees growing in a forest site in Slovenia $\left(46^{\circ} \mathrm{N}, 14^{\circ} 40^{\prime} \mathrm{E}, 400 \mathrm{~m}\right.$ a.s.I.) were studied on the cellular and subcellular level. Samples containing the cambial zone and developing xylem were taken from six beech trees every week throughout the 2006 vegetation period. Cell wall thickening and lignification in individual cell wall layers and cell types were determined by light microscopy, cellular UV-microspectrophotometry and transmission electron microscopy, respectively. Cell division started between the 18th and the 24th of April 2006. Lignification began in the newly formed xylem tissue on the 2nd of May. After 1 month, the developing earlywood portion contained fully differentiated vessels with completed wall deposition and lignification, and differentiated fibres and axial parenchyma became visible after 2 months. At the end of cambial cell division on the 9th August, the differentiation of the most recently formed fibres in the terminal zone of the growth ring continued for approximately 4 weeks. This indicates that the process of lignification in earlywood is slower than in latewood. The high temporal resolution of the investigated processes and the combination of the above-mentioned microscopic techniques provides a detailed insight into the process of cell wall thickening and lignification of woody tissue in beech.
\end{abstract}

Keywords: beech (Fagus sylvatica); cellular UV-microspectrophotometry (UMSP); cell wall; fibres; lignin; topochemical analysis; transmission electron microscopy (TEM); vessels; wood formation.

${ }^{*}$ Dedicated to Prof. Dr. Eckstein on the occasion of his 70th birthday.

\section{Introduction}

The differentiation of tracheary elements and fibres in xylem can be divided into four successive stages: cell expansion, deposition of multilayered secondary cell wall, lignifications, and cell death (Plomion et al. 2001). Formation of the cell walls is amongst the most obvious features of the differentiation of xylem elements (Chaffey 1999).

Cell wall thickening and lignification have already been studied from different points of view: (1) lignin distribution within annual growth rings (Fukazawa and Imagawa 1981; Takabe et al. 1992), (2) studies of heterogeneous cellular distribution of guaiacyl and syringyl lignins (Fergus and Goring 1970a; Yoshinaga et al. 1997; Ruel et al. 1999; Terashima 2000), and (3) lignification dynamics of different cell types (Nakashima et al. 1997; Grünwald et al. 2002; Gričar et al. 2005). Numerous methods, such as microautoradiography, histochemistry, interference microscopy, fluorescence microscopy, transmission electron microscopy (TEM), and cellular UV-microspectrophotometry (UMSP), have been used to reveal structural and chemical details (e.g., Murmanis and Sachs 1969; Terashima and Fukushima 1989; Donaldson et al. 1999; Donaldson 2001; Koch and Kleist 2001; Schmitt and Melcher 2003; Koch and Grünwald 2004; Gričar et al. 2006, 2007a).

Studies of the differentiation dynamics in the wood of angiosperms at the ultra-structural level are rare. Yoshinaga et al. (1997) investigated the stages of lignification in oak xylem by measuring cell wall thickness and UVabsorbance values in relation to the distance from the cambial zone. Grünwald et al. (2002) applied the same method to compare cell differentiation and lignification in wild and transgenic aspen trees. Dünisch et al. (2003) investigated the kinetics of cell differentiation in Swietenia macrophylla with high resolution laser measurements, in situ, following cell enlargement and cell differentiation at very short time intervals, showing how fast the individual cells were formed.

Topochemical investigation of cell wall formation and lignification throughout the vegetation period have surprisingly not yet been carried out in beech (Fagus sylvatica $\mathrm{L}$.), which is amongst the most common and most important tree species in Europe. The aim of this study is to present the differentiation in vessels, fibres, and axial parenchyma of beech (Fagus sylvatica) wood with special emphasis on cell-wall formation and lignification. For this purpose, tissue samples were taken from living trees every week throughout the 2006 vegetation period and were studied with light microscopy (LM), UMSP, and TEM. 


\section{Material and methods}

\section{Material}

Tissue samples containing phloem, cambial zone, and outer xylem were collected from six beech (Fagus sylvatica L.) trees aged over 100 years growing at a forest site near Ljubljana, Slovenia (approximately $46^{\circ} \mathrm{N}, 14^{\circ} 40^{\prime} \mathrm{E}, 400 \mathrm{~m}$ a.s.l.). The samples $\left(25 \times 10 \times 10 \mathrm{~mm}^{3}\right)$ were taken from living trees $(1.3 \mathrm{~m}$ above ground) at weekly intervals from April to September 2006 with a chisel and knife. To avoid the effect of wounding, the distance between neighbouring samples was at least $10 \mathrm{~cm}$, so that the new sample would not contain traumatic tissues or woundwood, which can be formed as a response of the cambium to mechanical damage (Gričar 2007). After removal, the samples were fixed in formalin-ethanol-acetic acid (FEA) solution for 1 week, rinsed with water and stored in $70 \%$ ethanol for further processing.

\section{Light microscopy (LM)}

For $\mathrm{LM}$, the specimens $\left(5 \times 5 \times 15 \mathrm{~mm}^{3}\right)$ from all six trees were embedded in paraffin using a Leica TP 1020-1 tissue processor (Rossi et al. 2006). Cross-sections (12 $\mu \mathrm{m}$ thick) were cut with a Leica RM 2245 rotary microtome, stained with safranine and astra blue in ethanol, embedded in euparal and examined with a Nikon Eclipse E800 microscope (transmission and polarised light modes) (e.g., Schmitt et al. 2003; Gričar et al. 2007b). LM was also used for the determination of onset and end of divisions in cambial zone, as well as for measuring the current year increments and for the evaluation of cell differentiation.

\section{UV-microspectrophotometry (UMSP) and measurements of cell wall thicknesses}

For UMSP and TEM, parallel sample blocks $\left(2 \times 2 \times 3 \mathrm{~mm}^{3}\right)$ from three representative trees were prepared, dehydrated, and embedded in Spurr's epoxy resin (Spurr 1969).

For UMSP, semi-thin sections $(1 \mu \mathrm{m})$ were cut with an Ultracut $E$ (Reichert-Jung) ultramicrotome equipped with a diamond knife. Sections were then mounted on quartz slides, immersed in a drop of non-UV-absorbing glycerine and covered with a quartz coverslip.

For UV spectroscopic investigations, an immersion ultrafluar objective 32:1 was applied. The ZEISS UMSP 80 microspectrophotometer was equipped with a scanning stage enabling the determination of image profiles at a constant wavelength with the scan programme APAMOS $^{\circledR}$ (Zeiss). For topochemical detection of lignin within individual cell wall layers, a wavelength of $278 \mathrm{~nm}$ (absorbance maximum of hardwood lignin) was selected (Koch and Kleist 2001; Koch 2004; Koch and Grünwald 2004; Röder et al. 2004; Lehringer et al. 2008). The scan programme digitised rectangular fields with a local geometric resolution of $0.25 \mu \mathrm{m} \times 0.25 \mu \mathrm{m}$ and a photometric resolution of 4096 greyscale levels, which were converted into 14 basic colours to visualise the absorbance intensities. The scans were depicted as two- and three-dimensional image profiles with statistical evaluation of UV-absorbance. Photometric point-by-point measurements were also performed with a spot size of $1 \mu \mathrm{m}^{2}$, between 240 and $400 \mathrm{~nm}$ in 1-nm steps. The programme LAMWIN ${ }^{\circledR}$ (Zeiss) was used, which recorded spectra of the lignified cell walls. The measurements were automatically repeated 50 times for each point analysis. UV-absorbance spectra were taken for selected samples of two trees, selected at the beginning (9th May 2006) and the end (22nd August 2006) of the vegetation period. Individual spectra were taken from cell corner (CC) and compound middle lamellae (CML) regions as well as from secondary cell walls (S2) of fibres, vessels, and axial parenchyma cells.
The positions of the local maxima in the UV-spectra reveal different chemical composition of lignin. Depending on the syringyl/guaiacyl ratio in the cell wall, the maximum shifts either to shorter or higher wavelengths (Takabe et al. 1992; Koch and Grünwald 2004).

A parallel set of semi-thin sections was stained with toluidine blue and examined by LM for better orientation (mapping of the sections) when using the UMSP device. Cell wall thicknesses were measured from the same sections with the image analysis system Analysis 5.0 (SIS, Olympus) and an Olympus AX 70 microscope.

Radial cell wall dimensions (i.e., single cell wall thicknesses measured from the lumen to the middle lamella) were measured in three trees for samples taken from the 2 nd of May to the 20th of June. We always measured the cell walls of 15 fibres and vessels in a tangential row next to the annual ring boundary. Then, the average thicknesses $\left(X_{i}\right)$ were calculated based on measurements in all trees on every sampling date.

Further, rates of cell wall development $\left(R W D_{i}\right)$ were calculated for the first formed fibres as follows:

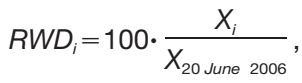

where $X_{i}$ is the average single cell wall thickness on the deliberate date of sampling and $X_{20}$ June 2006 is the average single cell wall thickness of the completely formed cells on the 20th of June 2006.

To evaluate the rate of cell wall carbohydrate deposition, the rates of weekly cell wall thickness increments $\left(R W I_{i}\right)$ were calculated as follows:

$R W I_{i}=100 \cdot \frac{X_{i}-X_{i-1}}{X_{20 \text { June 2006 }}}$,

where $X_{i-1}$ is the single radial cell wall thickness from the previous date.

\section{Transmission electron microscopy (TEM)}

Samples embedded in Spurr's epoxy resin (Spurr 1969) were used for TEM. For these studies, ultra-thin transverse sections (80-100 nm thick) were cut and stained with potassium permanganate according to Donaldson (1992). Examination was carried out with a Philips CM 12 TEM at accelerating voltages of 40 or $60 \mathrm{kV}$ to enhance contrast.

\section{Results}

The development of xylem cells in the selected beech trees during the 2006 growing season is presented in Table 1 and Figures 1-6. Particular attention was given to the development of the first formed (initial part of the growth ring, Figure 1a) and last formed cells (terminal part of the growth ring, Figure 1b) in three trees.

Cambial cell divisions and wood formation started in all trees between the 18th and the 24th of April 2006 (Table 1). Reactivation of the cambial zone was determined by tangential cell divisions and subsequent radial expansion of the newly formed xylem cells (Figure 1a). One week later (between the 24th of April and the 2nd of May 2006), the onset of deposition of secondary wall (S) carbohydrates was observed in fibres (Figures 2a and $3 a)$. On the 2 nd of May the cell walls of the fibres were thin (Figure 4) and only low absorbance values were 
Table 1 Development of wood tissue at cellular and subcellular levels in mature beech (Fagus sylvatica) trees growing near Ljubljana $\left(46^{\circ} \mathrm{N}, 14^{\circ} 40^{\prime} \mathrm{E}, 400 \mathrm{~m}\right.$ a.s.I.).

\begin{tabular}{|c|c|c|c|}
\hline Date 2006 & Process & $\begin{array}{l}\text { Absorbance values } \\
\text { waveleng }\end{array}$ & $278 \mathrm{~nm}$ \\
\hline 18th to 24th April & Reactivation of cambial zone, first new xylem cells formed & & $\begin{array}{l}\text { Initial } \\
\text { zone }\end{array}$ \\
\hline 24th April to 2nd May & $\begin{array}{l}\text { Vessels and fibres - deposition of secondary wall (S) } \\
\text { started }\end{array}$ & & \\
\hline 2nd May & $\begin{array}{l}\text { Vessels and fibres near the rays-first lignin deposition in } \\
\text { cell corners (CCs) and compound middle lamellae (CML) }\end{array}$ & & \\
\hline 9th May & $\begin{array}{l}\text { Vessels - deposition of S2 completed } \\
\text { Vessels and fibres - lignification of CC, CML and S1 }\end{array}$ & $\begin{array}{l}0.09-0.16(\mathrm{CML})^{\mathrm{a}} \\
0.16-0.22(\mathrm{CC})^{\mathrm{a}} \\
0.22-0.29(\mathrm{CC})^{\mathrm{b}}\end{array}$ & \\
\hline 16th May & $\begin{array}{l}\text { Vessels - deposition of S3 and lignification of S2 and S3 } \\
\text { completed } \\
\text { Fibres - 50\% of cell wall deposited, S2 starts to lignify, } \\
\text { more lignin (higher UV absorption) in radial walls }\end{array}$ & $\begin{array}{l}0.11-0.22(\mathrm{CML})^{\mathrm{a}} \\
0.29-0.35(\mathrm{CC})^{\mathrm{a}} \\
0.07-0.14(\mathrm{~S} 2)^{\mathrm{a}} \\
0.16-0.22(\mathrm{~S} 2)^{\mathrm{b}}\end{array}$ & \\
\hline 30th May & $\begin{array}{l}\text { Vessels - warty layer } \mathrm{W} \text { formed, differentiation completed } \\
\text { Fibres }-70 \% \text { of cell wall completed }\end{array}$ & $\begin{array}{l}0.22-0.29(\mathrm{CML})^{\mathrm{a}} \\
0.29-0.35(\mathrm{CC})^{\mathrm{a}} \\
0.09-0.16(\mathrm{~S} 2)^{\mathrm{a}} \\
0.16-0.29(\mathrm{~S} 2)^{\mathrm{b}}\end{array}$ & \\
\hline 20th June & $\begin{array}{l}\text { Fibres - deposition of cell wall and lignification completed, } \\
\text { no plasma in the cells, UV absorption lower than in the } \\
\text { vessels } \\
\text { Axial parenchyma - differentiation completed } \\
\text { Clear differentiation of first formed fibres and axial } \\
\text { parenchyma - } 60 \% \text { of the annual ring } 2006 \text { deposited in } \\
\text { all trees, it contains mature cells and cells in all } \\
\text { phases of differentiation } \\
\text { Cambial zone, divisions and the width start to decrease } \\
\text { after this date }\end{array}$ & $\begin{array}{l}0.19-0.29(\mathrm{CML})^{\mathrm{a}} \\
0.41-0.54(\mathrm{CC})^{\mathrm{a}} \\
0.09-0.21(\mathrm{~S} 2)^{\mathrm{a}} \\
0.16-0.29(\mathrm{~S} 2)^{\mathrm{b}}\end{array}$ & \\
\hline 9th August & $\begin{array}{l}\text { Cambial zone - cessation of divisions in all trees } \\
\text { In } 17 \text { cell layers below cambial zone - differentiation } \\
\text { not yet completed }\end{array}$ & & $\begin{array}{l}\text { Terminal } \\
\text { zone }\end{array}$ \\
\hline 16th August & $\begin{array}{l}\text { In } 13 \text { cell layers below cambial zone - differentiation } \\
\text { not yet completed }\end{array}$ & & \\
\hline 5th to 12 th September & Differentiation completed, all cells lignified & $\begin{array}{l}0.29-0.35(\mathrm{CML})^{\mathrm{a}} \\
0.54-0.61(\mathrm{CC})^{\mathrm{a}} \\
0.22-0.29(\mathrm{~S} 2)^{\mathrm{a}} \\
0.16-0.17(\mathrm{~S} 2)^{\mathrm{b}}\end{array}$ & \\
\hline
\end{tabular}

${ }^{a} U V$ - absorbance values in fibre cell wall; ${ }^{b} U V$ - absorbance values in vessel cell wall.

detected in the newly formed xylem tissue (Figure 5a,f). The exceptions were the cell corners (CCs) and the compound middle lamellae (CML) in the fibres and vessels adjacent to ray parenchyma with low UV-absorbance values in the range of $a^{b} s_{278} 0.09$ to 0.17 . At the same time, the deposition of carbohydrates was completed in $\mathrm{S} 1$ and the formation of S2 started (Figure 2a).

The completely thickened S1 and part of the S2 layers of vessels, with an average cell-wall thickness of $1.5 \mu \mathrm{m}$, were found in samples taken on the 9th of May (Figure $2 b)$. At the same time, lignification started in CC and CML regions of vessels and fibres (Figure $5 b, g$ ). The UV-absorbance values in CCs of fibres $\left(\mathrm{abs}_{278} 0.16-0.22\right)$ were slightly higher than in CML ( $\mathrm{abs}_{278} 0.09$ and 0.16 ) and the cell walls of vessels showed overall higher absorbance values ( $\mathrm{CC}$ abs ${ }_{278} 0.22$ and 0.29$)$. The S1 layer seemed to start with lignification between the 9th and the 16th of May. In general, the absorbance values were first detected in radial and then in tangential walls. At the beginning of the growth season, the deposition of lignin proceeded faster in tree nr. 3 than in the other two trees (not shown).

In the first formed vessels, S3 layer carbohydrates were deposited until the 16th of May (Figure 3c) and also the lignification appeared to be fully completed (Figure 5c,h). $A b_{278}$ was $0.16-0.22$ in the middle part of vessel $\mathrm{S} 2$ and increased towards the layers near the CML $\left(a_{278} 0.29-0.35\right)$. These findings on the lignification of vessel walls were confirmed by TEM of samples stained with potassium permanganate (Figure 3c). On several samples, a warty layer (W) was observed in the first formed vessels on the 30th of May. It was shown that the deposition of cell wall carbohydrates and lignification was completed in the first formed vessels between the 16 th of May and the 30th of May 2006, i.e., approximately 1 month after their formation.

The cell walls of fibres thickened more slowly than those of vessels. In the first formed fibres, approximately $50 \%$ of the cell wall carbohydrates had been deposited 


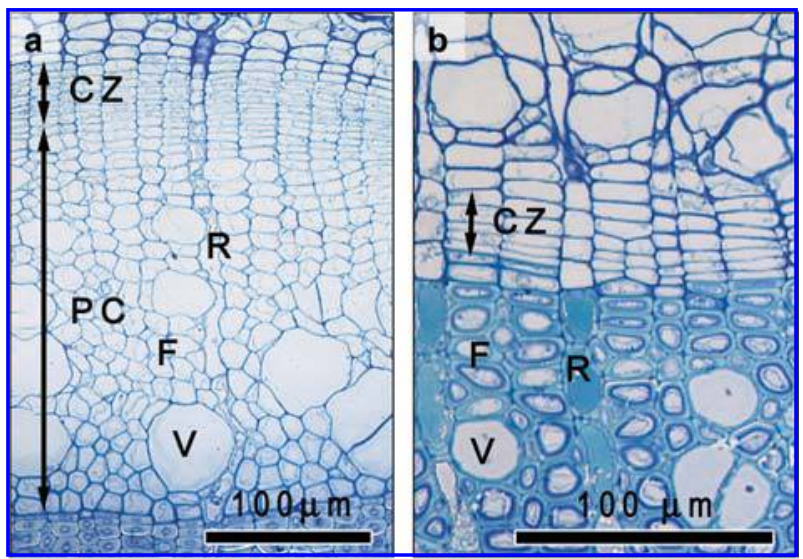

Figure 1 Cross-sections of beech (Fagus sylvatica) tissues under light microscope, toluidine blue staining. (a) Active cambial zone (CZ) on the 2nd of May 2006 and the current growth ring consists of enlarging thin-walled cells (PC) and cells, in which the deposition of secondary wall (SW) is initiated; (b) dormant CZ on the 9th of August 2006; below it, latewood cells are visible in the final stage of differentiation. V - vessel, F - fibre, $R$ - ray.

by the 16th of May (mean radial thickness of $2.5 \mu \mathrm{m}$ ) (Figure 4), whereby the outer S2 just started to lignify. At that time, the average absorbance values in CCs were between $a b s_{278} 0.29$ and 0.35 and in CML between $a^{278}$ 0.15 and 0.22 . The absorbances in the $\mathrm{S} 2$ walls were still

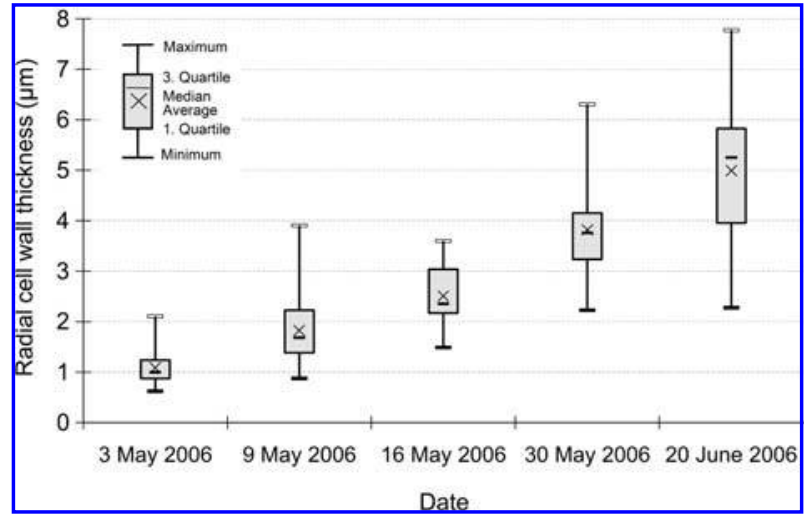

Figure 4 Radial cell wall thickening of first formed fibres after their formation between the 18th and the 24th of April 2006.

low, around $\mathrm{abs}_{278}$ 0.09. The lignin content in $\mathrm{CML}$ of the tangential cell walls $\left(\mathrm{abs}_{278} 0.09-0.16\right)$ was lower than in the radial cell walls $\left(a_{2 b s} 0.16-0.22\right)$. Two weeks later, on the 30th of May, approximately $70 \%$ of the fibre wall had been formed (Figure 2c), and from the 20th of June onwards, the fibre wall thickness remained constant indicating that carbohydrate deposition was completed.

On the 20th of June, i.e., approximately 2 months after the onset of cambial divisions, the first fully differentiated fibres were observed near the growth ring boundary. The mean thickness of their cell walls was $5 \mu \mathrm{m}$ (range

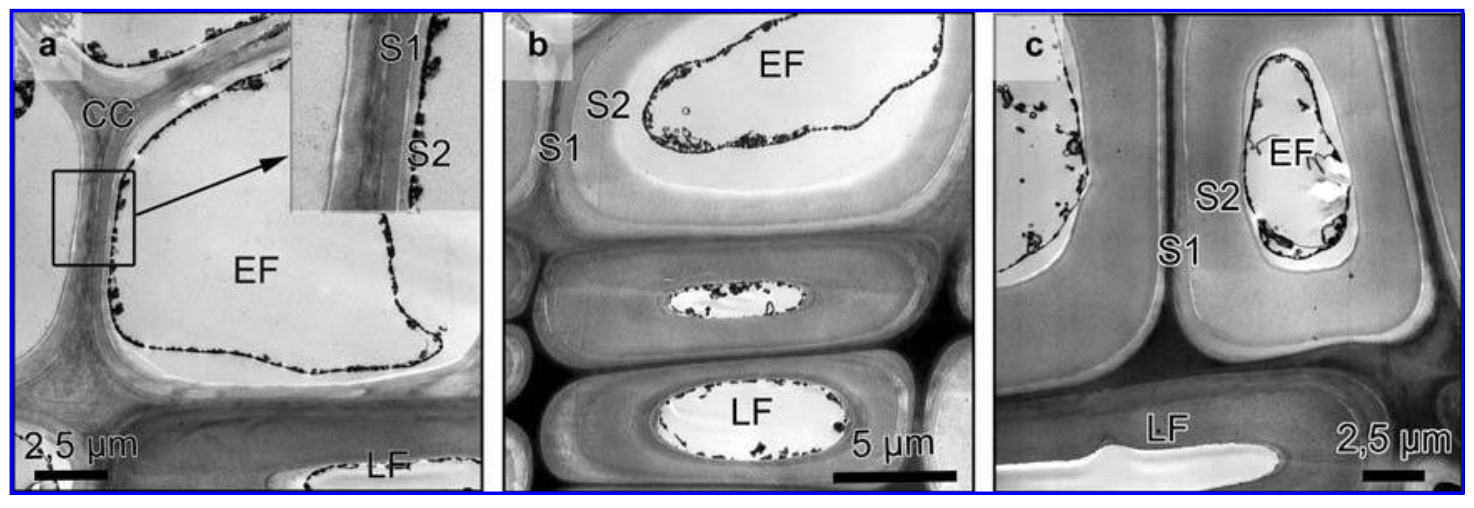

Figure 2 TEM micrographs of the cells near the growth ring boundary in beech wood with completely formed latewood fibres (LF) of the 2005 growth ring and developing first formed fibres (EF) of the 2006 growth ring in different phases of cell wall development. Dates of sampling: (a) 2nd May, (b) 9th May, and (c) 30th May 2006. S1, S2 - layers of the secondary cell wall, CC - cell corner.

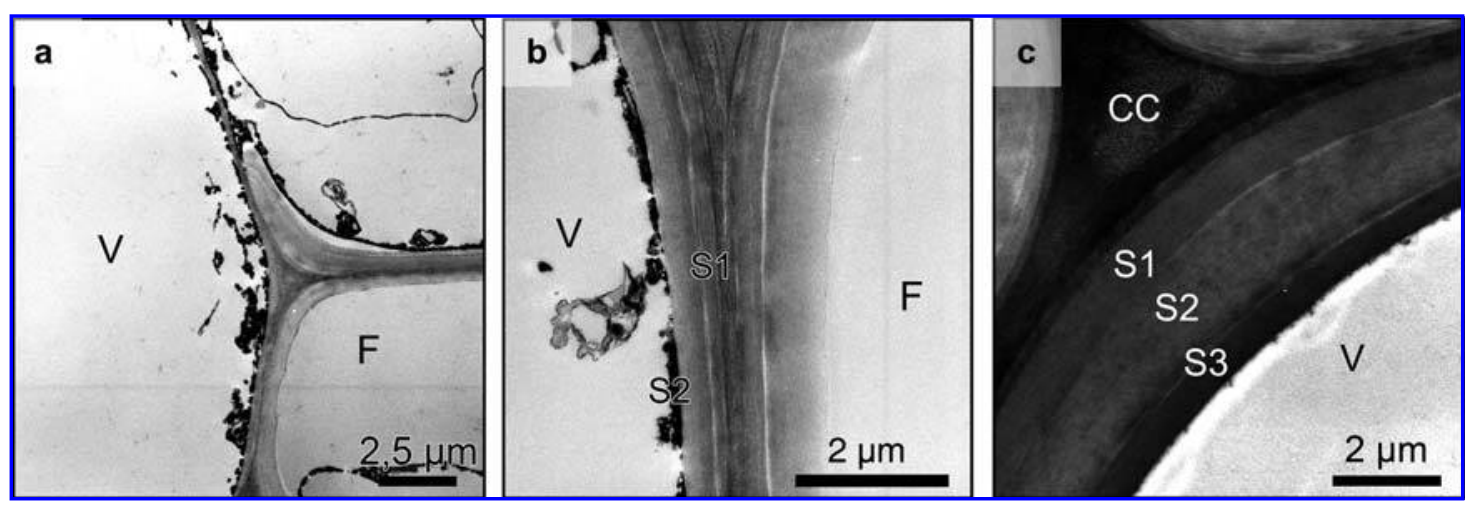

Figure 3 TEM micrographs of a transverse section through developing beech wood vessels $(\mathrm{V})$ and fibres $(\mathrm{F})$ with cell walls in different phases of development on: (a) 2nd May, (b) 9th May, and (c) 16th May 2006. S1, S2, S3 - layers of the secondary cell wall, CC - cell corner. 


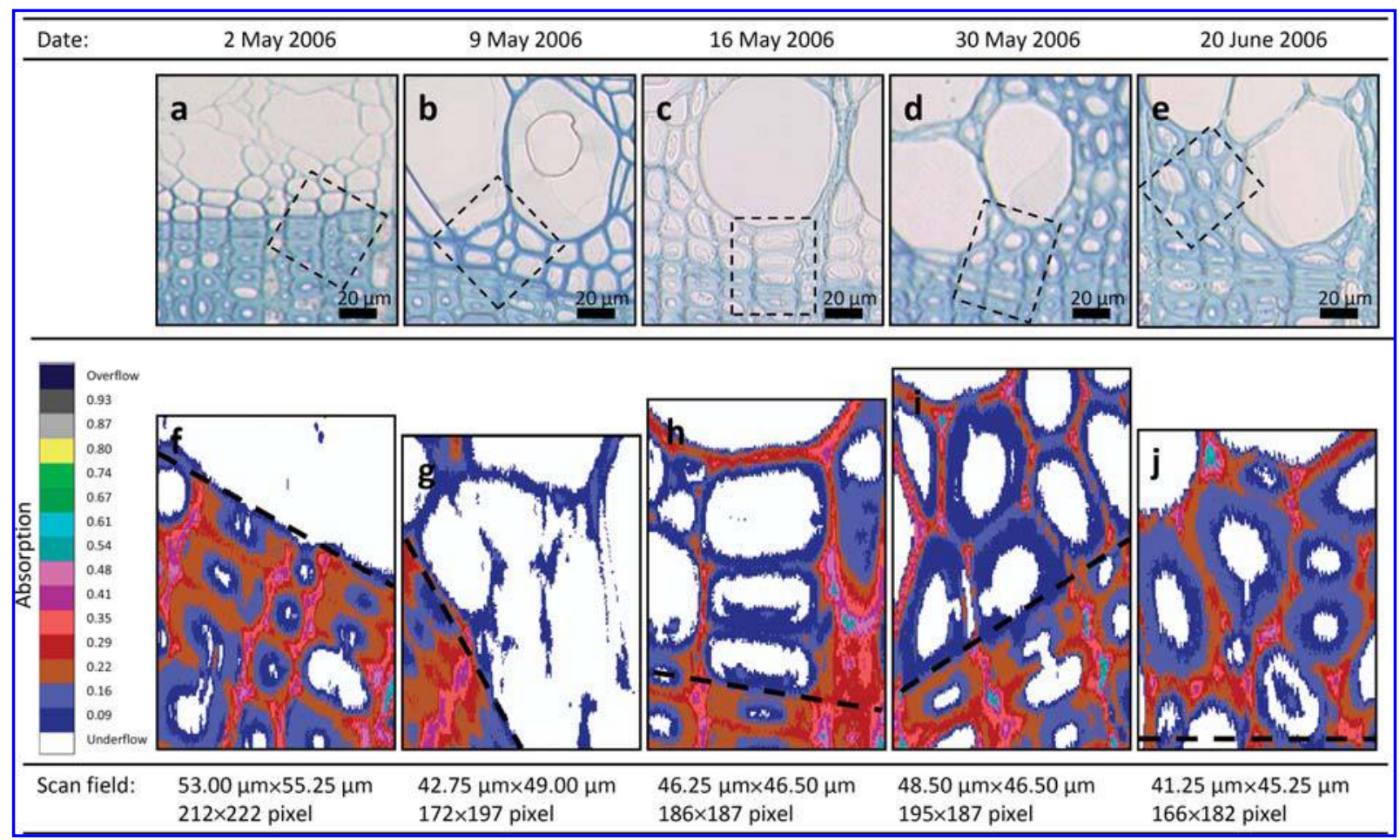

Figure 5 Progressive differentiation and lignification of new formed xylem tissue in tree $\mathrm{nr}$. 1 from the 2nd of May to the 20th of June 2006. (a-e) Light microscopic pictures of the first formed tissue near the growth ring boundary stained with toluidine blue showing different stages of cell wall development; the frames indicate the area of scanning fields. ( $f-j)$ Images of UMSP analysis showing the absorbance values at different stages of cell wall lignification; black dashed lines indicate the growth ring boundaries. The progressive lignification can be followed from (f) no absorbance detected on the 2nd of May to (j) maximal absorbance of completely formed fibres on the 20th of June 2006.

4.5-5.5 $\mu \mathrm{m}$ ) (Figure 4). The UV-absorbances of their secondary walls varied between abs $_{278} 0.16$ and 0.20 . Corresponding data were higher in the CML (between $\mathrm{abs}_{278} 0.22$ and 0.29), and the highest in the CC (between $\mathrm{abs}_{278} 0.41$ and 0.54 ). The cell lumina of fibres and vessels at this time were without cytoplasm, which indicated that differentiation was completed. We also observed that the absorbances of fibre S2 layers were uniformly distributed (Figure 5e,j). The rate of cell wall deposition was relatively uniform; in the first 5 weeks, approximately $14 \%$ of the radial cell wall was formed per week, and in the last 3 weeks the rate was approximately $8 \%$.

It was nearly impossible to follow cell wall deposition in axial parenchyma. During the initial phases of differentiation, both axial parenchyma cells and fibres were characterised by thin walls; their pits (the most important features to differentiate between them) were not yet formed and their lumina contained cytoplasm. Fibres and axial parenchyma could be distinguished when the thickness of the differentiating fibre wall reached approximately $70 \%$. At this stage, the fibre walls were thicker than the axial parenchyma cell walls. The walls of differentiated axial parenchyma cells were on average $1.9 \mu \mathrm{m}$ thick, or 2.5 times less than the fibre walls.

The first formed axial and ray parenchyma cells were fully differentiated by the 20th of June. At that time, their S2 layers showed $a s_{278}$ values of $0.25-0.29$ and they contained starch grains in the lumina. The corresponding data of the ray parenchyma cell walls varied from $a \mathrm{bs}_{278}$ 0.09 near the lumen to $\mathrm{abs}_{278} 0.29$ in the CML (image not shown). Many of the ray cells contained highly UV- absorbing substances in the cytoplasm, with $a^{b} s_{278}$ around 0.74 .

By the 20th of June, the width of the 2006 growth rings in all trees comprised at least $60 \%$ of the final width and contained mature cells and cells in all stages of differentiation. From this date onwards, the rate of cambial cell division slowed down and the cambial zone became reduced, but the differentiation of the latest formed xylem cells continued.

We also analysed the differentiation of fibres, vessels, and axial parenchyma cells of the terminal zone of the growth ring. In trees nr. 1, nr. 2, and nr. 3, cambial divisions stopped around the 9th of August (Figure 1b). Thereafter, the cambial zone contained on average five cell rows, and the latest formed xylem cells neighbouring the cambial zone were not yet fully differentiated. Fully differentiated fibres were characterised by their UVabsorbances in CCs, CML, and S2 analogous to those in mature tissue $\left(a_{278} \quad 0.29-0.32\right.$ for $\mathrm{CC}, \mathrm{abs}_{278}$ 0.19-0.22 for CML, and $a^{2} s_{278} 0.09-0.21$ for S2). The cells from approximately the 30th to the 1st cell layer below the cambial zone were therefore not yet fully differentiated. In xylem cells close to the cambial zone, lignification started in the CC and CML, as already described for the older xylem cells. The abs ${ }_{278}$ values at this date were around 0.09 in CML and around 0.16 in CC.

On the 16th of August, differentiation was completed in the 22nd to 16 th cell rows, while the 15th to 13th cell rows still showed UV-absorbance $\left(a^{2} s_{278} 0.17\right)$ lower than in mature cells. On the 22nd of August, the lignification of CCs and CML in some fibres close to the cambial zone 


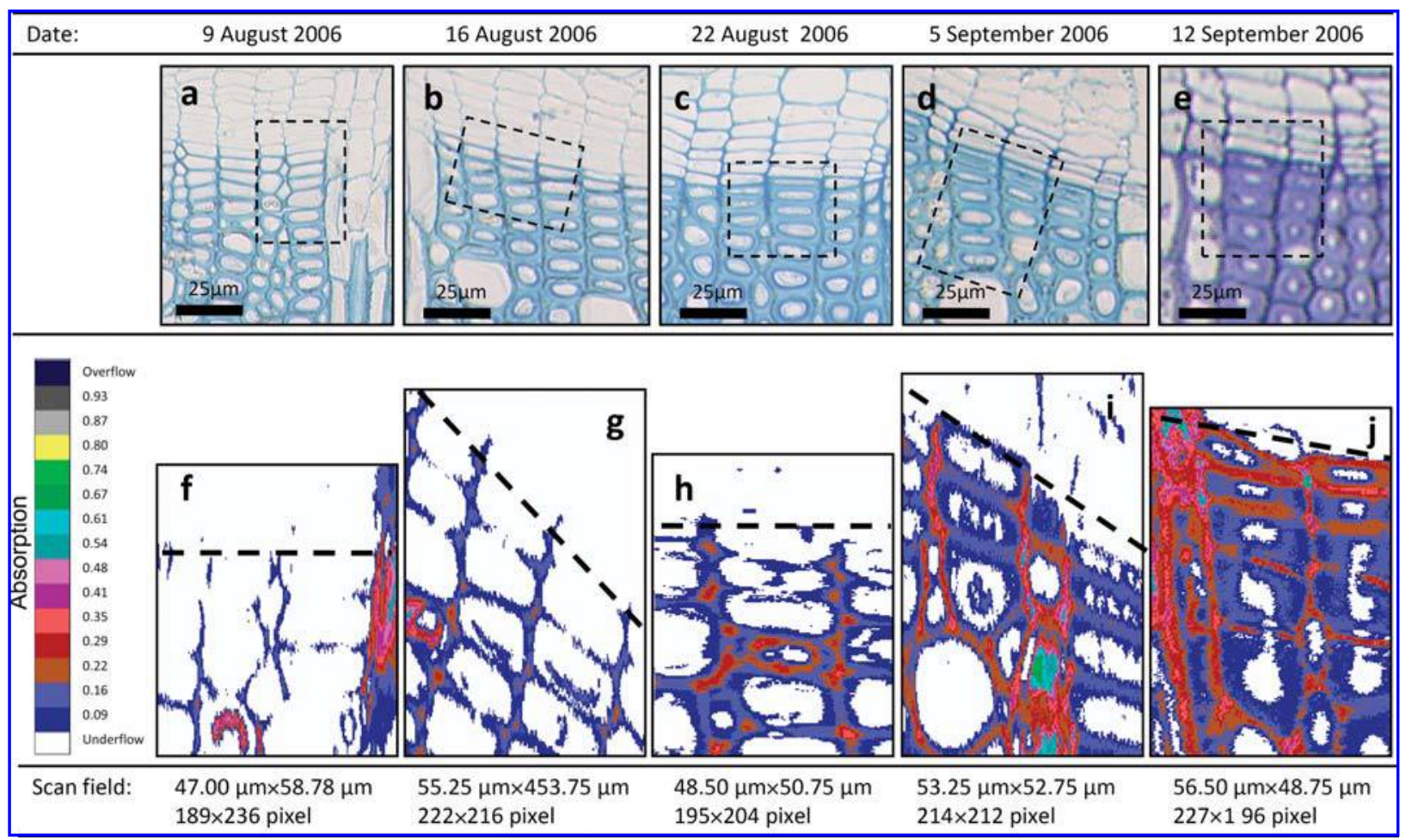

Figure 6 Progress of differentiation of terminal fibres in 2006 growth ring of tree $\mathrm{nr} .1$ from the 9th of August to the 12th of September. $(a-e)$ Light microscopic pictures of terminal fibres below cambial zone stained with toluidine blue showing different stages of cell wall development; the frames indicate the area of scanning fields. (f-j) Images of UMSP analysis showing the absorbance values at different stages of cell wall lignification; black dashed lines indicate the boundary between the wood and dormant cambial zone. The progressive lignification can be followed from (f) low absorbance values in slightly lignified CCs and CML of terminal fibres on the 9th of August to (j) completely lignified terminal fibres with maximal absorbance values on the 12th of September 2006.

was still in progress. Between the 5th and the 12th of September, all cells in the current growth ring were fully differentiated (Figure 6). The $\mathrm{abs}_{278}$ data in the S2 of fibre walls varied between 0.22 and 0.29 .

The last formed vessels were located between the 15th and 4th cell row below the cambial zone, and their lignification ended until the 5th of September. The absorbances of completely formed vessel cell walls were lower than in those in the initial zone and varied between abs $_{278}$ 0.16 in $\mathrm{S} 2$ and 0.22 in CML (Figure 6i). The $\mathrm{abs}_{278}$ values of ray parenchyma cell walls adjacent to the cambial zone were high, ranging from 0.35 to 0.41 .

The results also indicated that the fibres in the terminal zone displayed somewhat higher absorbances (around $\mathrm{abs}_{287}$ 0.22) than those in the initial zone (Figures 5 and 6). Comparing the spectral behaviour of the fibre walls in the initial and in the terminal part of the growth ring, there were observed shifts of the UV-absorbance maxima to higher wavelengths. These shifts amounted up to $3 \mathrm{~nm}$, which indicated that the content of guaiacyl lignin was higher in the terminal part.

Point measurements at wavelengths from $240 \mathrm{~nm}$ to $400 \mathrm{~nm}$ provided information on the lignin composition of different morphological regions in beech xylem. In Figure 7, representative UV spectra of individual cell wall layers are shown. UV spectra of vessel and fibre walls have absorbance maxima at wavelengths of 280 and $278 \mathrm{~nm}$. The absorbances of vessel S2 layer $\left(\mathrm{abs}_{280} 0.29\right)$

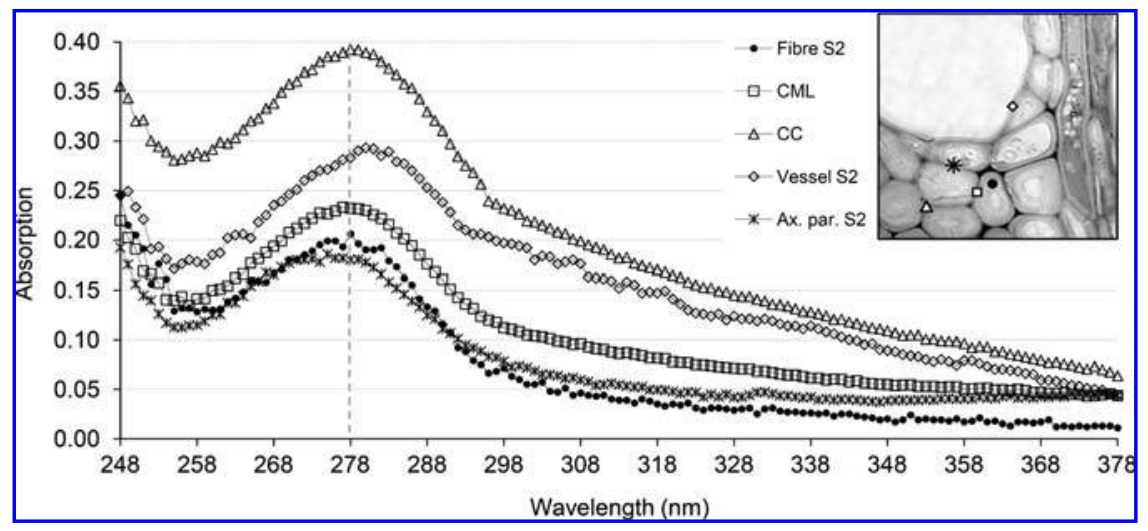

Figure 7 UV-absorbance spectra of different morphological regions in the first half of the 2006 xylem growth ring in beech: cell corner (CC) and compound middle lamella (CML) between two fibres and secondary cell walls (S2) of fibre, vessel, and axial parenchyma. 
were higher than those in fibre $\mathrm{S} 2\left(\mathrm{abs}_{278} 0.19\right)$. The lignin in CCs showed the same spectral behaviour as vessel S2 lignin. The absorbance maximum of CML and S2 layers of fibres and axial parenchyma cells lay at a wavelength of $278 \mathrm{~nm}$, whereas in vessels it was at $280 \mathrm{~nm}$. The lignin concentration was almost equal in fibre and in the axial parenchyma cell wall, but slightly higher in the CML.

\section{Discussion}

The results indicate that the differentiation of first formed vessels in developing xylem tissue of beech was completed within 1 month after the onset of cambial divisions. On the 30th of May, many of the first formed vessels contained a warty layer. The warty layer therefore seems to be more frequent in Fagus sylvatica than in Fagus crenata, for which Ohtani and Ishida (1976) observed that only very few earlywood vessels contained it. Vessel differentiation proved to be faster than the differentiation of fibres, which took 2 months. This finding is in agreement with observations of Yoshinaga et al. (1997) in oak xylem. The same authors also reported that the cell wall thickening progressed in two phases in oak fibres, whereby the first was faster and the second slower. Our observations similarly revealed that the weekly rate of cell wall thickening was slightly higher during the first 5 weeks and lower in the last 3 weeks.

Lignification first started in CCs and CML of vessel and fibre walls. It occurred earlier in cell walls of vessels and fibres close to ray parenchyma, which is in agreement with observations of Donaldson (2001) in conifers. Lignin incorporation proceeded centripetally towards the lumen, first in radial CML. As the S1 started to lignify during S2 formation, the lignin content still increased in CC and CML. Murakami et al. (1999) found that the lignification of S2 in neighbouring vessels and ray cells started earlier than in fibres and ray cells without direct pit contact with adjacent vessel elements. The course of lignification observed in our studies corresponded to that in previous studies in angiosperms and gymnosperms (Saleh et al. 1967; Fengel and Wegener 1989; Donaldson 2001; Mellerowicz et al. 2001).

The rate of lignification differed slightly amongst the investigated trees, and during the growth season. This depended on both internal and external factors. Donaldson (1991), for example, suggested that lignification is sensitive to environmental conditions, such as temperature and light, which also affects the incorporation of different lignin types (Grand et al. 1979).

Our results of semi-quantitative determination of lignin contents in individual cell wall layers in beech are in agreement with those found by Koch and Grünwald (2004) in the same wood species. Evaluation of the scanning profiles and spectra showed a homogeneous distribution of the absorbance values in fibre S2, as also described by Koch and Kleist (2001). The results obtained by UMSP were confirmed by TEM analysis, which also revealed a homogeneous lignin distribution, as indicated by an even staining with potassium permanganate. For comparison, the absorbance values for
$\mathrm{CC}$ and $\mathrm{CML}$ regions were double of those in S2, which is in agreement with findings of Koch and Grünwald (2004).

Studies based on point measurements were necessary for determining the chemical composition of lignin. The spectral curves of vessel and fibre walls differed in the position of their maxima. The UV-absorbance maxima at a wavelength of $280 \mathrm{~nm}$ are characteristic of vessels, whereas those at $278 \mathrm{~nm}$ are characteristic of fibre walls. This indicates that the walls of these two cell types obviously have a different lignin composition, with a greater amount of strongly absorbing guaiacyl lignin in vessels and more syringyl units in fibres, as previously reported by Fergus and Goring (1970a,b), Musha and Goring (1975), and Terashima (2000).

Several authors, e.g., Yoshinaga et al. (1997) and Terashima (2000), have suggested that the reason for the different chemical composition of fibres and vessels is the successive incrustation of different monolignols ( $p$ hydroxyphenyl, guaiacyl, and syringyl) at different stages of differentiation. Yoshinaga et al. (1997) reported that vessel walls of oak show maximal UV-absorbances at 280 to $285 \mathrm{~nm}$ during cell wall thickening, but they later become stable at approximately $280 \mathrm{~nm}$. These authors also found that the fibres in oak show maximal absorbances at 280 to $285 \mathrm{~nm}$ during the first stage of cell differentiation, as similarly observed for vessels. During later stages of differentiation, the UV maxima shifted to a shorter wavelength of approximately $273 \mathrm{~nm}$.

The point measurements also revealed that ray and axial parenchyma cell and fibre walls absorb at a similar wavelength of $278 \mathrm{~nm}$. Fergus and Goring (1970a) investigated birch tissue and reached the same conclusions.

In the present study, cell wall lignification was analysed in the initial and in the terminal zone of current year growth rings in beech. Takabe et al. (1992), who studied the distribution of guaiacyl and syringyl lignin throughout the entire growth ring of Fagus crenata, found that the ratio between syringyl and guaiacyl lignin varied within the growth ring. Our results showed that fibres in the terminal zone have slightly higher absorbance values and higher electron densities than those in the initial zone. Vessels, however, have somewhat lower values in the terminal part of the growth ring. When comparing the spectral behaviour of fibre and vessel walls in the initial with those in the terminal part of the growth ring, a shift of the UV-absorbance maxima towards higher wavelength from 279 to $280 \mathrm{~nm}$ occurred in fibres, whereas in vessel walls the maxima shifted towards 279 to $278 \mathrm{~nm}$. This indicates that the guaiacyl lignin content is higher in the terminal fibres, whereas in the last formed vessels syringyl lignin content seems to be higher.

The observations also showed that differentiation of the last formed fibres and vessels continued for approximately 1 month after cessation of cambial divisions. Similar conclusions were also drawn for terminal cells of various conifers, such as Pinus radiata, Abies alba and Picea abies (e.g., Donaldson 1992; Gričar et al. 2005; Gričar and Čufar 2008), but also in Fagus sylvatica (Čufar et al. 2008b,c). Our data indicated that lignification in beech seemed to be completed faster than in conifers. A comparison of Figures 5 and 6 confirms that the lig- 
nification of fibre cell walls proceeded more slowly in the initial part of the growth ring (by approximately 1 month) than in the terminal part, whereas vessels lignified a bit slower in the terminal part (for approximately 2 weeks). Various authors suggested that cell walls rich in guaiacyl lignin thickened rapidly and lignified slowly, while walls rich in syringyl lignin both thickened and lignified slowly (Yoshinaga et al. 1997; Donaldson 2001). The present data clearly demonstrate that fibres in the terminal zone, which predominantly consisted of guaiacyl lignin, lignified faster and vessels with higher syringyl amount lignified slower than in the initial zone.

Our study also confirmed that the potassium permanganate staining used for TEM appears very helpful for demonstrating lignin distribution in the various cell wall layers with high resolution. However, this technique does not provide information on the lignin composition, as ideally obtained with cellular UMSP (Schmitt and Melcher 2003; Schmitt et al. 2003; Gričar et al. 2005; Frankenstein et al. 2006; Čufar et al. 2008a).

\section{Conclusions}

Tissues were sampled from mature living trees at weekly time intervals and it was possible to analyse xylem cell development and lignification on the cellular and subcellular level in combination with the methods LM, UMSP, and TEM. UMSP enabled semi-quantitative determination of the lignin concentration during the vegetation period and visualisation of topochemical changes in developing xylem tissue. Staining with potassium permanganate and high resolution TEM confirmed the results obtained by UMSP. Detailed results on the differentiation and lignification of the walls of different xylem cells could be elaborated.

\section{Acknowledgements}

This work was supported by the Slovenian Research Agency, young researchers' programme and the programme P4-0015, and by the LLP ERASMUS bilateral agreement between the University of Ljubljana and the University of Hamburg. We thank Tanja Potsch and Magda Tušek Žnidarič for their immense help in the laboratory.

\section{References}

Chaffey, N. (1999) Cambium: old challenges - new opportunities. Trees 13:138-151.

Čufar, K., Gričar, J., Zupančič, M., Koch, G., Schmitt, U. (2008a) Anatomy, cell wall structure and topochemistry of waterlogged archaeological wood aged 5,200 and 4,500 years. IAWA J. 29:55-68.

Čufar, K., Prislan, P., de Luis, M., Gričar, J. (2008b) Tree-ring variation, wood formation and phenology of beech (Fagus sylvatica) from a representative site in Slovenia, SE Central Europe. Trees 22:749-758.

Čufar, K., Prislan, P., Gričar, J. (2008c) Cambial activity and wood formation in beech (Fagus sylvatica) during the 2006 growth season. Wood Res. 53:1-12.
Donaldson, L.A. (1991) Seasonal changes in lignin distribution during tracheid development in Pinus radiata D. Don. Wood Sci. Technol. 25:15-24.

Donaldson, L.A. (1992) Lignin distribution during latewood formation in Pinus radiata D. Don. IAWA Bull. 13:381-387.

Donaldson, L.A. (2001) Lignification and lignin topochemistry an ultrastructural view. Phytochemistry 57:859-873.

Donaldson, L.A., Singh, A.P., Yoshinaga, A., Takabe, K. (1999) Lignin distribution in mild compression wood of Pinus radiata. Can. J. Bot. 77:41-50.

Dünisch, O., Schulte, M., Kruse, K. (2003) Cambial growth of Swietenia macrophylla King studied under controlled conditions by high resolution laser measurements. Holzforschung 57:196-206.

Fengel, D., Wegener, G. Wood: Chemistry, Ultrastructure, Reactions. De Gruyter, Berlin/New York, 1989.

Fergus, B.J., Goring, D.A.I. (1970a) The location of guaiacyl and syringyl lignins in birch xylem tissue. Holzforschung 24:113117.

Fergus, B.J., Goring, D.A.I. (1970b) The distribution of lignin in birch wood as determined by ultraviolet microscopy. Holzforschung 24:118-124.

Frankenstein, C., Schmitt, U., Koch, G. (2006) Topochemical studies on modified lignin distribution in the xylem of poplar (Populus spp.) after wounding. Ann. Bot. 97:195-204.

Fukazawa, K., Imagawa, H. (1981) Quantitative analysis of lignin using an UV microscopic image analyser. Variation within one growth increment. Wood Sci. Technol. 15:45-55.

Grand, C., Ranjeva, R., Boudet, A.M., Alibert, G. (1979) Photoregulation of the incorporation of guaiacyl units into lignins. Planta 146:281-286.

Gričar, J. (2007) Xylo- and Phloemogenesis in Silver Fir (Abies alba Mill.) and Norway Spruce (Picea abies (L.) Karst.). Slovenian Forestry Institute, Ljubljana, 2007.

Gričar, J., Čufar, K. (2008) Seasonal dynamics of phloem and xylem formation in silver fir and Norway spruce as affected by drought. Russ. J. Plant Physiol. 55:538-543.

Gričar, J., Čufar, K., Oven, P., Schmitt, U. (2005) Differentiation of terminal latewood tracheids in silver fir trees during autumn. Ann. Bot. 95:959-965.

Gričar, J., Zupančič, M., Čufar, K., Koch, G., Schmitt, U., Oven, P. (2006) Effect of local heating and cooling on cambial activity and cell differentiation in the stem of Norway spruce (Picea abies). Ann. Bot. 97:943-951.

Gričar, J., Zupančič, M., Čufar, K., Oven, P. (2007a) Regular cambial activity and xylem and phloem formation in locally heated and cooled stem portions of Norway spruce. Wood Sci. Technol. 41:463-475.

Gričar, J., Zupančič, M., Čufar, K., Oven, P. (2007b) Wood formation in Norway spruce (Picea abies) studied by pinning and intact tissue sampling method. Wood Res. 52:1-10.

Grünwald, C., Ruel, K., Schmitt, U. (2002) Differentiation of xylem cells in rolC transgenic aspen trees - a study of secondary cell wall development. Ann. Forest Sci. 59:679-685.

Koch, G. (2004) Biologische und chemische Untersuchungen über Inhaltsstoffe im Holzgewebe von Buche (Fagus sylvatica L.) und Kirschbaum (Prunus serotina Borkh.) und deren Bedeutung für Holzverfärbungen. Kommissionsverlag Max Wiedebusch, Hamburg, 2004.

Koch, G., Kleist, G. (2001) Application of scanning UV microspectrophotometry to localise lignins and phenolic extractives in plant cell walls. Holzforschung 55:563-567.

Koch, G., Grünwald, C. (2004) Application of UV microspectrophotometry for the topochemical detection of lignin and phenolic extractives in wood fibre cell walls. In: Wood Fibre Cell Walls: Methods to Study their Formation, Structure and Properties. Eds. Schmitt, U., Ander, P., Barnett, J.R., Emons, A.M.C., Jeronimidis, G., Saranpää, P., Stanzl- Tschegg, S. Swedish University of Agricultural Sciences, Uppsala. pp. 119-129. 
Lehringer, C., Gierlinger, N., Koch, G. (2008) Topochemical investigation on tension wood fibers of Acer spp., Fagus sylvatica L. and Quercus robur L. Holzforschung 62:255-263.

Mellerowicz, E.J., Baucher, M., Sundberg, B., Boerjan, W. (2001) Unravelling cell wall formation in woody dicot stem. Plant Mol. Biol. 47:239-274.

Murakami, Y., Funada, R., Sano, Y., Ohtani, J. (1999) The differentiation of contact cells and isolation cells in the xylem ray parenchyma of Populus maximowiczii. Ann. Bot. 84:429-435.

Murmanis, L., Sachs, B.I. (1969) Seasonal development of secondary xylem in Pinus Strobus L. Wood Sci. Technol. 3:177193.

Musha, Y., Goring, D.A.I. (1975) Distribution of syringyl and guaiacyl moieties in hardwoods as indicated by ultraviolet microscopy. Wood Sci. Technol. 9:45-58.

Nakashima, J., Mizuno, T., Takabe, K., Fujita, M., Saiki, H. (1997) Direct visualization of lignifying secondary wall thickenings in Zinnia elegans cells in culture. Plant Cell Physiol. 38: 818-827.

Ohtani, J., Ishida, S. (1976) An observation on perforation plate differentiation in Fagus crenata BI., using scanning electron microscopy. Res. Bull. College Exp. Forests 23:115-126.

Plomion, C., Le Provost, G., Stokes, A. (2001) Wood formation in trees. Plant Physiol. 127:1513-1523.

Röder, T., Koch, G., Sixta, H. (2004) Application of confocal Raman spectroscopy for the topochemical distribution of lignin and cellulose in plant cell walls of beech wood (Fagus sylvatica L.) compared to UV microspectrophotometry. $\mathrm{Holz-}$ forschung 58:480-482.

Rossi, S., Anfodillo, T., Menardi, R. (2006) Trephor: a new tool for sampling microcores from tree stems. IAWA J. 27:89-97.

Ruel, K., Burlar, V., Joseleau, J.P. (1999) Relationship between ultrastructural topochemistry of lignin and wood properties. IAWA J. 20:203-211.
Saleh, T.M., Leney, I., Sarkanen, K.V. (1967) Radiographic studies of cottonwood, Douglas fir, and wheat plants. Holzforschung 21:116-120.

Schmitt, U., Melcher, E. (2003) Section staining with potassium permanganate for transmission electron microscopy: a useful tool for lignin localisation. In: Wood Fibre Cell Walls: Methods to Study their Formation, Structure and Properties. Eds. Schmitt, U., Ander, P., Barnett, J.R., Emons, A.M.C., Jeronimidis, G., Saranpää, P., Stanzl-Tschegg, S. Swedish University of Agricultural Sciences, Uppsala. pp. 105-118.

Schmitt, U., Grünwald, C., Gričar, J., Koch, G., Čufar, K. (2003) Wall structure of terminal latewood tracheids of healthy and declining silver fir trees in the Dinaric region, Slovenia. IAWA J. 24:41-51.

Spurr, A.R. (1969) A low viscosity embedding medium for electron microscopy. J. Ultrastruct. Res. 26:31-43.

Takabe, K., Miyauchi, S., Tsunoda, R., Fukazawa, K. (1992) Distribution of guaiacyl and syringyl lignins in Japanese beech (Fagus-Crenata) - variation within an annual ring. IAWA Bull. 13:105-112.

Terashima, N. (2000) Formation and ultrastructure of lignified plant cell walls. In: New Horizons in Wood Anatomy. Eds. Kim, Y.S. Chonnam National University Press, Kwangju. pp. 169-180.

Terashima, N., Fukushima, K. (1989) Biogenesis and structure of macromolecular lignin in the cell wall of tree xylem as studied by microautoradiography. In: Plant Cell Wall Polymers, Biogenesis and Biodegradation. Eds. Lewis, N.G., Paice, M.G. American Chemical Society, Washington, DC. pp. 160-168.

Yoshinaga, A., Fujita, M., Saiki, H. (1997) Secondary wall thickening and lignification of oak xylem components during latewood formation. Mokuzai Gakkaishi 43:377-383.

Received November 14, 2008. Accepted February 19, 2009. Previously published online May 7, 2009. 